\title{
DERIVATIONAL AFFIXES FORMING NOUN IN FIREFLY LANE NOVEL BY KRISTIN HANNAH
}

\author{
Ni Luh Putu Ardiningsih ${ }^{1}$, I Komang Sulatra ${ }^{2}$, Putu Devi Maharani ${ }^{3}$ \\ 1,2,3English Study Program Faculty of Foreign Languages \\ Mahasaraswati Denpasar University, Jl. Kamboja No.11A Denpasar, \\ Bali - Indonesia \\ niputuardini1@gmail.com, ${ }^{1}$ soelatra01@yahoo.com, ${ }^{2}$ \\ devmaharani86@gmail.com ${ }^{3}$
}

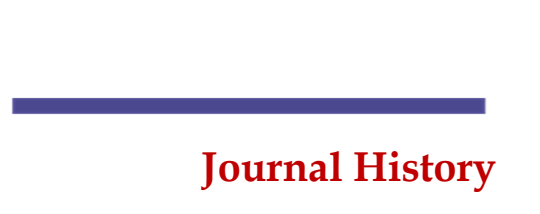

Submitted $11^{\text {th }}$ Februari 2021

Revised 25 th March 2021

Accepted 25th April 2021

Published 29th July 2021

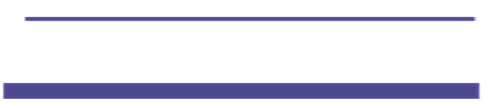

Keywords:

Morphology, Derivational, Affixes And Noun

\begin{abstract}
This study aims to find out the types of derivational affixes forming noun and the functions of derivational affixes forming noun in the novel entitled Firefly Lane written by Kristin Hannah. The methods used in this study are quantitative and qualitative methods. This study used observation method in collecting the data from all chapters in the novel Firefly Lane. Finally, this writing concludes that there were two functions of derivational affixes such are: class changing affixes and class maintaining affixes and each function has two types which are: prefixes and suffixes. The result of the study found there are 3 prefixes forming noun such are: re-, pre-, and pro-, and from suffixes there were found 22 suffixes forming noun, they are: -er, -hood, -ism, -ist, -ity, -ship, -ness, -th, -ize, -less, -ous, -y, -ful, -ive, -ing, -ance, -ence, -ant, -ion, -ment, - or, and-ure.
\end{abstract}

\section{INTRODUCTION}

In mastering the second language such as English language one of the important aspects is mastering vocabularies. Vocabularies can help us more communicative to talk with the native speaker or in learning foreign language. Newman\&Dwyer (2009: 385) say that vocabularies play the important role in language since it refers to the words to communicate effectively. Vocabulary can be divided into two types, for instance: expressive vocabulary or words in speaking and receptive vocabulary or words in listening. There are so many ways to improve the vocabularies beside by reading book and through dictionary there is also important to 
know how to form word in English.According to Aitchison (1992:4) linguistics is scientifically studied about rules, system and principles of human language. Morphology is one of the branches in linguistic that study about word-structure in the terms of morpheme as the smallest meaningful unit. Lieber (2010) defines that "morphology is a study of word-formation including the ways new word are coined in the languages of the world, and the way forms of words are varied depending on how they are used in the sentence." In linguistics affix is a morpheme which is attached to a word stem or base to form a new word. Affixation also could be the way to improve our vocabularies, since affixation forming one word with one meaning into another word with another meaning. There are three types of affixes, they are: prefix, infix, and suffix, however in English infixation is very rare happen. Affix can be divided into two major function categories, it is called: derivational morpheme and inflectional morpheme. The difference of those derivational and inflectional morphemes is emphasizing. Derivational affixes change the category of word class and modify the meaning, but not for inflectional morpheme it does not alter the word class only modifies the meaning so it could be fit into the particular syntactic slot (Katamba, 1993:53).

This study focuses on the analysis of derivational affixes forming noun, which used the data from a novel, entitled Firefly Lane by Kristin Hannah. The researcher has chosen this topic since it is very interesting and unique part of the derivational affixes that forming noun is the mostly found and has the largest class of words in the most language such as in English. Frank (1972) says, there are only nouns, verbs, adjective and adverbs as forms of derivational. The process of derivational affixes also can help the language second learners to improve their vocabularies which are essential to the part of English grammar. The novel Firefly Lane was chosen because it provides abounded of word with derivational affixes forming noun as the required data that can be good representative data source to be analyzed on how the affixes derived other words and modify the meaning.

There are various types of literary works such are newspaper, magazine, novel, poem and book. This study was chosen novel Firefly Lane as the data source because it provides many words including derivational affixes forming noun. Novel defined as fiction narrative that develops in eighteen century in England. It is structurally differs from the epic since has more complex characters and dealing with human experience which considerable length and complexity (Klarer, 1999:9-10).

This study is conducted to analyzed the types and functions of derivational using the McCarthy's and Katamba's theory, especially for derivational forming noun since it has the more productive word class than the others. The researcher gained the data from the novel Firefly Lane which 
has the powerful story about love, loss and friendship. This novel written by Kristin Hannah in 2008 as a best author's of nineteen novels.

\section{METHODS}

In analyzing the data, it used quantitative qualitative methods. The quantitative method used to show the percentage of derivational affixes forming noun found in the novel. Furthermore, the result followed with descriptive information which belongs to qualitative method. This study took the data from a novel entitled Firefly Lane written by Kristin Hannah. The novel published in 2008 and consists of 479 pages or 37 chapters. The story was about two best friends who came from a different family background, they are Tully Hart and Kate Murkeley.

In collecting the data, this study used the observation method. It was done by several steps. The first step was reading the whole novel carefully and intensively to get more understanding of whole points. The second step was taking notes of the derivational words and quoting the sentences of the words found in the novel Firefly Lane Written by Kristin Hannah in 2008. The third step was finding out the word meaning and word class of each data in the English Dictionary. The last step was classifying the data based on the affix's variation found in the novel Firefly Lane Written by Kristin Hannah 2008.

\section{RESULTS AND DISCUSSION}

Based on the analysis of types and functions of derivational affixes forming noun, there are 204 data found from the novel Firefly Lane written by Kristin Hannah. There are from class maintaining prefixes forming noun with 7 words found, from class maintaining suffix forming noun there are 18 words found, from class changing suffix forming noun there are 179 words found, meanwhile in class changing prefixes there are not found any affixes forming noun. Thus, the occurrences of any affixes forming noun will be shown below:

Table 1. Table of Function Derivational Affixes Forming Noun Found in the Firefly Lane Novel

\begin{tabular}{|c|c|c|c|c|}
\hline No. & $\begin{array}{l}\text { Function of } \\
\text { Derivational Affixes }\end{array}$ & Types & Occurrences & Percentage \\
\hline \multirow[t]{2}{*}{1.} & \multirow{2}{*}{$\begin{array}{lr}\text { Class } & \text { Maintaining } \\
\text { Affixes } & \\
\text { Class } & \text { Changing }\end{array}$} & Prefixes & 7 & $3,4 \%$ \\
\hline & & Suffixes & 18 & $8,9 \%$ \\
\hline \multirow[t]{2}{*}{2.} & $\begin{array}{ll}\text { Class } & \text { Changing } \\
\text { Affixes } & \\
\end{array}$ & Suffixes & 179 & $87,7 \%$ \\
\hline & & & 204 & $100 \%$ \\
\hline
\end{tabular}


According to the table 1, it can be seen that there are two functions of derivational affixes found in Firefly Lane novel they are class maintaining affixes and class changing affixes. After collecting the data, there were two hundred and four words using derivational affixes forming noun. From the class maintaining affixes there are 25 words found with 7 words in prefixes $(3,4 \%)$ and 18 word in suffixes $(8,9 \%)$, however in class changing suffixes there are 179 words found $(87,7 \%)$ but there is not found from the prefixes. The most prefix used in the class maintaining is prefix $r e-$, the most suffix used in the class maintaining suffix is suffix -ist and -er, meanwhile in class changing suffix the most used is suffix -ion. Class changing affixes is the dominant function of derivational affixes in this data source.

Table 2. Table of Derivational Affixes Forming Noun Found in the Firefly Lane Novel

\begin{tabular}{|c|c|c|c|}
\hline \multicolumn{2}{|c|}{$\begin{array}{l}\text { Derivational Affixes Forming } \\
\text { Noun }\end{array}$} & \multirow[t]{2}{*}{ Frequency } & \multirow[t]{2}{*}{ Percentage } \\
\hline Prefixes & Suffixes & & \\
\hline Re- & & 4 & $2 \%$ \\
\hline Pre- & & 2 & $1 \%$ \\
\hline \multirow[t]{13}{*}{ Pro- } & & 1 & $0,5 \%$ \\
\hline & -er & 16 & $7,8 \%$ \\
\hline & -hood & 3 & $1,5 \%$ \\
\hline & -ity & 16 & $7,8 \%$ \\
\hline & -ship & 2 & $1 \%$ \\
\hline & -ism & 3 & $1,5 \%$ \\
\hline & -ist & 4 & $2 \%$ \\
\hline & -ness & 20 & $9,8 \%$ \\
\hline & -th & 3 & $1,5 \%$ \\
\hline & -ize & 3 & $1,5 \%$ \\
\hline & -less & 14 & $6,9 \%$ \\
\hline & -ous & 8 & $3,9 \%$ \\
\hline & $-y$ & 14 & $6,9 \%$ \\
\hline
\end{tabular}




\begin{tabular}{c|ccc} 
& -ful & 2 & $1 \%$ \\
\hline & -ive & 5 & $2,5 \%$ \\
\hline -ing & 6 & $2,9 \%$ \\
\hline -ance & 3 & $1,5 \%$ \\
\hline & -ence & 4 & $2 \%$ \\
\hline & -ant & 1 & $0,5 \%$ \\
\hline & -ion & 48 & $23,5 \%$ \\
\hline & -ment & 14 & $6,9 \%$ \\
\hline & -or & 6 & $2,9 \%$ \\
\hline & -ure & 204 & $1 \%$ \\
\hline & Total & & $100 \%$ \\
\hline
\end{tabular}

According to the table 2 above, it can be seen that there are two types of derivational affixes found in the Firefly Lane novel which are prefixes and suffixes. There are 204 data found which divided into 3 types of prefixes forming noun and 22 types suffixes forming noun. From the table, it can be shows the total number of occurrences in prefixes re-with 4 words $(2 \%)$, pre- with 2 words (1\%) and pro- with 1 word (0,5\%), meanwhile for the total number of suffixes -er and -ity both with 16 words $(7,8 \%)$, -hood, -ism, -th, ize with 3 words $(1,5 \%)$, -ship, -ful,-ure with 2 words (1\%), -ist and -ence with 4 words $(2 \%)$, -ness with 20 words $(9,8 \%)$, -less, -y, -ment with 14 words $(6,9 \%)$, -ous with 8 words $(3,9 \%)$, -ivewith 5 words $(2,5 \%)$, -ing and -or with 6 words $(2,9 \%)$, -ant with 1 word $(0,5 \%)$, and the last is suffix -ion with 48 words $(23,5 \%)$ as the most suffix found in forming noun.

\section{DISCUSSION}

This research which discussed about the kinds and the process of English derivational affixes forming noun. The types and function of derivational affixes were analyzed by using the theory proposed by Katamba (1993) and McCarthy (2002). There were two functions of derivational affixes such are: class maintaining affixes and class changing affixes, each of them is divided again into its category namely prefixes and suffixes. This study found the types are noun derived from noun, noun derived from adjective, and noun derived from verb. 


\subsection{Class Maintaining Affixes}

Based on the data source, it was found 25 words that consist into this type. The affixes came from 7 words belonging to the prefixes and 18 words belonging to the suffixes. Those are prefixes: re-, pre-, pro- and suffixes -er, hood, -ism, -ist, -ity. -ship. The data found in the Firefly Lane novel explained below:

\section{Prefix re-}

Data 1: "A mother-daughter reunion would be TV gold."(Firefly Lane: 328)

From the data above the word reunion is a case of class maintaining derivation, since that word class from the root union becomes reunion still belong to the same word class as a noun. For the better explanation the diagram showed as below:

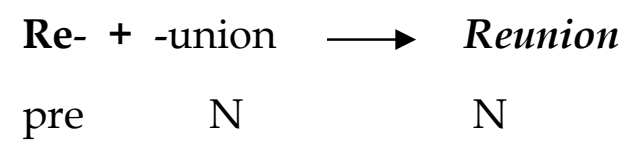

The prefix of the word reunion is re-. The root of the word above is union which categorized as a noun means an organization of workers usually in particular industry, that exists to protect their interest and improve the condition of work. Meanwhile after adding by prefix re-, it becomes reunion which means meeting of former friend or colleagues which are in a long time not meeting each other. The addition of prefix re- is the word above does not change the word class but it change the identity of the word only.

\section{Suffix -ist}

Data 2: "Inside the overly quaint space, Tully took a seat in the lobby, close to the empty receptionist desk." (Firefly Lane: 74)

Based on the example above, the word receptionist has added by suffix -ist from the root reception. The word reception is categorized as a noun which means part of hotel or office building where visitor are receipt. It has modified the meaning of the word receptionist after added by suffix -ist which means person whose job is to deal with visitor to a hotel or office building, without changing the word class of a word base. The diagram below showed for a clearer explanation:

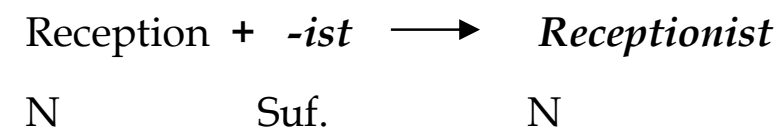

This is thus a case of class maintaining derivation. The addition of suffix -ist in the word above does not alter the word class. It only changes the identity of the word only into the meaning 'devotee of or expert on'. 


\subsection{Class Changing Suffix}

In process of collecting the data, that there were found 179 data which belonging to the class changing suffix only. The kinds of this type such are suffixes: -er, -ity, -ness, -th, -ize, -less, -ous, -y, -ful, -ive, -less, and ing. However there are only two data as the representative were analyzed. The process of analysis can be seen as follow.

\section{Suffix -ness}

Data 4: "Across the street up the hill, the pretty little farmhouse glowed against the darkness". (Firefly Lane: 30)

The suffix of the word darkness is -ness and the root of the word above is dark. The word dark is categorized as an adjective which means lack of lights and when it is attached by suffix -ness at the end of the root, the word class of darkness change into noun which means the states of being dark without any lights. Here is the diagram showed for the deeper understanding.

\section{Dark +-ness $\longrightarrow$ Darkness}

\section{Adj Suf. N}

From the diagram it can conclude that the input dark is become from the adjective and it turned into noun darkness, this is a case of class changing suffix because the process of derivation produces a the lexeme which belongs to other word class of the base. The addition of suffix -ness above has changed the word class and the identity of the word which means 'quality, state or, condition'.

\section{Suffix -ion}

Data 8:"A new feeling overtook her, it was a kind of breathless anticipation. "(Firefly Lane: 86)

Anticipation is formed by two morphemes. They are anticipate (free morpheme) and -ion (bound morpheme). The morpheme anticipate belongs to a verb which means see what might happen in the future and take action and when attached by suffix -ion in the end of the word base becomes anticipation which belongs to the noun means the fact of seeing something that might happen in the future and doing preventive things. This is thus a class changing derivation. From the process mentioned above here is showed the diagram that having the word class between input and output which are not in the same word class.

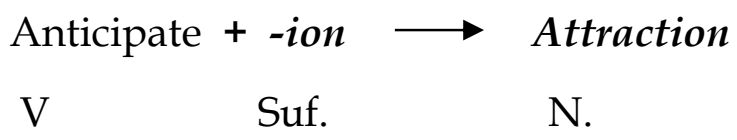


The addition of suffix -ion in the word above alter the word class of the base itself and also changes the identity of the word.

\section{CONCLUSION}

Based on result and discussion on the previous chapter, the writer concluded that there are 204 words found which are attached in the derivational affixes forming noun from the Firefly Lane novel written by Kristin Hannah. Those kinds of affixes are prefixes and suffixes in between the functions of class maintaining which is the process of derivation produces lexeme which belongs to the same form class as the base and class changing affixes or produces lexeme which belongs to other word class than the word class of the base. Those are can be divided into the word attached by prefixes 7 words $(3,4 \%)$ and 197 words (96.6\%) attached by suffixes. Furthermore, there are 3 types of prefixes found such are: $r e^{-}$, pre-, pro-, and for the types of suffixes there were 22 types found such are:-er, -ity, -hood, ism, -th, -ize, -ship, -ful, -ure, -ist, -ence, -ness, -less, -y, -ment, -ous, -ive-ing, or, -ant, and -ion.Suffix is the most dominant types of derivational in forming noun.

\section{REFERENCES}

Aitchison, J. (1992). Linguistics (Vol. 4). London Sydney Auckland: Hodder \& Stoughton Ltd.

Ardiningsih, Ni Luh Putu. 2021. A Morphological Analysis of Derivational Affixes found in the Novel Firefly Lane Written by Kristin Hannah. English Study Program, Faculty of Foreign Languages, Mahasaraswati Denpasar University

Bauer, Laurie. 2003. Introducing Linguistic Morphology. Edinburgh: J W Arrowsmith Ltd.

Brinton, Laurel J. 2000. The Structure of Modern English A Linguistic Introduction. Amsterdam: John Benjamin's publishing Company.

Carstairs-McCarthy, Andrew. 2002. An Introduction to English Morphology: Words and Their Structure. United Kingdom: Edinburgh Texts Book on the English Language.

Frank, Marcella. 1972. Modern English: A Practical References Guide. New Jersey: Prentice Hall, Inc.

Hannah, Kristin. 2008. Firefly Lane. New York: St Martin's Press.

Katamba, Francis. 1993. Morphology. United Kingdom: Macmillan Education. 
Katamba, Francis. 1994. English Words. New York: Routledge.

Klarer, Mario. 1999. An Introduction to Literary Studies. Darmstadt: WissenschaftlicheBuchgesellschaft.

Lieber, Rochelle. 2010. Introducing Morphology. Cambridge: Cambridge University Press.

Neuman, S.B. and Dwyer.J. 2009. Missing in Action: Vocabulary Instruction in Pre-K. The Reading Teacher. USA: New York University.

Plag,Ingo. 2002. Word-Formation in English. Deutch: Cambridge University Press Series 'Cambridge Textbooks in Linguistics'. 